12,000 were employed in biological and less than 5,000 in the physical sciences, and of the total, less than 15,000 were engaged in research and development, about half of whom were employed by the Department of Defense, mostly (86 per cent) as engineering or mechanics technicians.

\section{National Health Service}

Overseas interest in the British National Health Service has led the Pharmaceutical Society of Great Britain to prepare an informative booklet which aims to identify the historical roots from which the present Service has grown, to explain a little of the complex financial basis, to describe the general structure, and, in more detail, the pharmaceutical services (The British National Health Service : a Short Survey with particular reference to the Pharmaceutical Services. Pp. ii +22 . London: The Pharmaceutical Press, 1961. 5s.). Mention is also made of the main findings of some of the committees that have deliberated from time to time on the various problems affecting the Service. Although the booklet aims especially at supplying information to pharmacists and others overseas, it may also provide a suitable introduction to the intricacies of the profession for newly qualified pharmacists or pharmacy students in Britain. It should also serve as a refresher course for those pharmacists who, although familiar with the dayto-day forms and procedures of the Service as it affects them, are sometimes less sure about the general structure of which they form so integral a part.

\section{The United Kingdom and the Common Market}

UNDER the title The Common Market and the United Kingdom the Westminster Bank, Ltd., has issued an admirable concise guide to the European Economic Community and the possible effects on Britain of membership (Pp. 30. London: Westminster Bank, Ltd., 1961). After a brief introduction which notes the complications arising out of Britain's position in the Commonwealth, her obligations to the European Free Trade Area and the special problem presented by agriculture, the pamphlet describes the European Economic Community, its organization and progress and then seeks to assess the effects on the United Kingdom of entry into the Common Market, ineluding the effects on industry, on agriculture and on the consumer.

\section{The Polish Academy of Sciences}

IN the Review of the Polish Academy of Sciences for January-March 1961 (No. 1, Vol. VI), W. Nowacki assesses the research plans of the Academy's agencies for 1961-65, and S. Zolkiewski the present state of the social sciences and the humanities in Poland. Besides B. Swietochowski's account of the scientific work of the Wroclaw Agricultural College, which ineludes a full bibliography, the Review includes notes on the several research centres for thermoenergetics, forestry research, pharmacological research and general theory of organizat:on and on the Institute of Biochemistry and Biophysics and the Basic Raw Material Research Centre of the Institute of Physical Chemistry.

\section{Nature Conservation in Western Malaysia}

A SPECIAL issue of the Malayan Nature Journal has been prepared to mark the twenty-first anniversary of the Malayan Nature Society ("Nature Con- servation in Western Malaysia", 1961. Edited by J. Wyatt-Smith and P. B. Wycherley. Pp. viii $+261+$ 44 plates. Kuala Lumpur: The Malayan Nature Society, 1961. Soft back, 12s. 6d.; hard back, 17s. 6d.). It contains forty-five articles by forty-one contributors dealing with such topics as the Malayan Nature Society, 1940-61; conservation and education; the Malayan Forest Department and conservation; river control and conservation in Malaya; conservation problems of Malaya's hill stations; conservation in Penang; nature protection in North Borneo; ferns in Singapore; limestone hills near Ipoh; Batu caves. Kuala Lumpur; cave archrology in Malaya; the distribution of elephant, rhinoceros, seledang and tapir in the King George V National Park, Malaya; the Shwe U Daung, a rhinoceros sanctuary in Burma; the Udjung-Kuølon Nature Park, Java; Mount Kinabalu, North Borneo; and the Bako National Park, Sarawak. There are also a number of articles dealing with wild-life conservation in other lands. E. J. H. Corner, now reader in taxonomy at the University of Cambridge, and formerly assistant director of gardens, Straits Settlement, Singapore, contributes a stimulating introduction.

\section{Insects as Social Animals}

THe fourth congress of the International Union for the Study of Social Insects was held in Pavia during September 9-14, at the invitation of the president of the Italian section of the Union, Prof. Carlo Jucci. Some two hundred people took part and 72 papers were read. There were symposia on endocrinology, caste differentiation, symbiosis and gregarism, and sections devoted to bees and wasps, ants and termites. Among the contributors were Prof. P.-P. Grassé (evolution of symbiosis in termites), Prof. C. Jucci (comparative endocrinology of social insects), Prof. M. Lüscher (hormonal regulation of development in termites), Prof. K. Gösswald (acceptance and rejection of radioactive markers by solitary and social insects), and Prof. J. B. S. Haldane (statistical analysis of some data on ant and wasp behaviour). A well-arranged exhibition was another feature of the congress. This included historical documents relating to earlier workers on social insects-Grassi, Silvestri, Forel and others; scientific exhibits ranging from photographs of African ant-galls and Australian termite mounds, to anatomical preparations; and a section on control measures, which included exhibits showing the progress of termite control in Italian libraries, and the successful introduction of the wood ant, Formica rufa, for the biological control of pests in Italian forests. The proceedings of the congress are to be published in the series Symposia Genetica of the L. Spallanzani Zoological Institute, University of Pavia.

\section{Leucocyte Migration in Inflammation}

Sir Howard Florey and L. H. Grant, in an article appearing in a recent issue of the Journal of Pathology and Bacteriology (82, No. 1; July 1961), report investigations of the passage of leucocytes through the walls of blood vessels inflamed by ultra-violet light in rabbit tissues using electron microscope techniques. No clear morphological evidence was cbtained that the surface of the endothelium became 'sticky', although cccasionally electron-dense material was seen in relation to the endothelium. The leucocytes penetrate the endothelium by thrusting out pseudopodia, possibly down cell junctions, and passing through until they reach the basement membrane, collagen fibres and pre- 